\title{
A DISCRICIONARIEDADE ADMINISTRATIVA ENTRE AS DIMENSÕES OBJETIVA E SUBJETIVA DOS DIREITOS FUNDAMENTAIS SOCIAIS*
}

\begin{abstract}
Daniel Wunder Hachem
Professor dos Cursos de Graduação, Mestrado e Doutorado em Direito da Pontifícia Universidade Católica do Paraná e da Universidade Federal do Paraná (Curitiba/PR, Brasil). Doutor e Mestre em Direito do Estado pela Universidade Federal do Paraná. Professor do Corpo Docente Estável do Mestrado em Direito Administrativo da Universidad Nacional del Litoral (Argentina). Professor Visitante da Universidad Rovira $i$ Virgili (Espanha). Diretor Acadêmico do Núcleo de Investigações Constitucionais - NINC do PPGD-UFPR <www.ninc.com.br>. Více-Líder do Núcleo de Pesquisas em Políticas Públicas e Desenvolvimento Humano - NUEPD do PPGD-PUCPR. Coordenador Executivo, pelo Brasil, da Rede Docente Eurolatinoamericana de Derecho Administrativo. Membro do Foro Iberoamericano de Derecho Administrativo e da Asociación de Derecho Público del Mercosur. Editor Acadêmico da A\&C - Revista de Direito Administrativo e Constitucional. Coordenador Editorial da Revista Eurolatinoamericana de Derecho Administrativo (UNL) e da Revista de Investigações Constitucionais (UFPR). Coeditor da Revista de Direito Econômico e Socioambiental (PUCPR). Advogado. Site: <www.danielhachem.com>. E-mail: <danielhachem@gmail.com>.
\end{abstract}

Resumo: Há um silêncio da doutrina do direito administrativo no que diz respeito à discricionariedade administrativa em matéria de direitos fundamentais sociais. Para suprir essa lacuna, o artigo propõese a defender três ideias: (i) existe uma diferença entre situações que envolvem a discricionariedade administrativa quando o objeto de análise é a dimensão subjetiva dos direitos fundamentais e quando o foco examinado é a sua dimensão objetiva; (ii) eventuais referências genéricas à "discricionariedade da competência administrativa em matéria de direitos fundamentais" podem subverter o verdadeiro significado dessa categoria jurídica, convertendo-a em um coringa do Poder Público para acobertar omissões arbitrárias; (iii) a eficácia irradiante derivada da vertente objetiva dos direitos fundamentais reduz sobremaneira a discricionariedade administrativa, podendo chegar a suprimi-la a ponto de tornar vinculada a competência da Administração e obrigá-la a remover todos os entraves existentes e criar todas as condições necessárias para proporcionar a máxima satisfação de tais direitos e de interpretar todo o ordenamento jurídico da maneira mais apropriada à realização ótima dos valores subjacentes aos direitos fundamentais.

* Pesquisa desenvolvida no marco do projeto de pesquisa internacional financiado pela Convocatoria de Estancia como Profesor Visitante n. EL004674, Departamento de Dret Públic, Universitat Rovira $i$ Virgili (Tarragona, Espanha), promovido em conjunto pelo Núcleo de Pesquisas em Políticas Públicas e Desenvolvimento Humano - NUPED do Programa de Pós-Graduação em Direito da Pontifícia Universidade Católica do Paraná. 
Palavras-chave: Discricionariedade administrativa. Direitos fundamentais. Direitos sociais. Dimensão objetiva. Dimensão subjetiva.

Sumário: 1 Introdução - 2 A discricionariedade administrativa em relação às dimensões subjetiva e objetiva dos direitos fundamentais: aspectos distintivos $\mathbf{- 3}$ A referência genérica à "discricionariedade da competência administrativa em matéria de direitos fundamentais": o risco do joker do Poder Público para acobertar omissões arbitrárias - 4 Eficácia irradiante dos direitos fundamentais e redução da discricionariedade administrativa: preenchimento dos espaços de vazio normativo pela dimensão objetiva - $\mathbf{5}$ Conclusão - Referências

\section{Introdução}

O tema da vinculação ou discricionariedade das competências administrativas ganha enorme relevo quando se ingressa no terreno dos direitos fundamentais, mormente quando se está a discutir a sua função prestacional. É que, em última instância, do ponto de vista do direito administrativo, costuma-se apresentar o debate sobre a exigibilidade dessa faceta dos direitos fundamentais perante a Administração nos seguintes termos: se ao direito fundamental corresponde uma competência vinculada, ele seria exigivel e o Estado se veria obrigado a conceder a prestação, mas se a ele corresponde uma competência discricionária, sua exigibilidade não estaria garantida, já que a Administração teria um espaço de liberdade para decidir se o fornecimento da prestação estatal postulada é conveniente e oportuno. ${ }^{1}$

É interessante notar que a discussão habitualmente gira em torno da dimensão subjetiva dos direitos fundamentais, mais especialmente sob a perspectiva individual. É usual questionar-se: aquele sujeito singularmente determinado é titular de um direito subjetivo ao fornecimento gratuito de medicamentos? Ou à concessão de determinado benefício assistencial? Ou ao atendimento educacional especializado, por ser portador de deficiência física? A resposta geralmente dada é: “Depende: se a competência administrativa conferida pelo sistema normativo for vinculada, sim; se for discricionária, não”.2

1 Ainda que versando sobre o tema da discricionariedade administrativa em termos gerais (e não de forma específica em relação aos direitos fundamentais), confira-se a explicação de Maria Sylvia Zanella Di Pietro: “Diante de um poder vinculado, o particular tem um direito subjetivo de exigir da autoridade a edição de determinado ato, sob pena de, não o fazendo, sujeitar-se à correção judicial. Em outras hipóteses, (...) a lei deixa certa margem de liberdade de decisão diante do caso concreto, de tal modo que a autoridade poderá optar por uma dentre várias soluções possíveis, todas válidas perante o direito. Nesses casos, o poder da Administração é discricionário (...)". DI PIETRO, Maria Sylvia Zanella. Discricionariedade administrativa na Constituição de 1988. 3. ed. São Paulo: Atlas, 2012, p. 62.

2 A doutrina tradicional do Direito Administrativo costuma afirmar que a norma jurídica, por vezes, prevê a atividade que deve ser realizada pela Administração, mas deixa de dizer se ela pode ser exigida pelo 
Esse raciocínio - extremamente frequente - muitas vezes pode estar correto; porém, se a questão for posta em termos gerais e abstratos, ele nem sempre se revelará acertado. Além disso, ele não resolve, por si só, o problema em tela. E isso por três motivos, que serão tratados nos seguintes tópicos: (2) há diferença entre situações que envolvem a discricionariedade administrativa quando o objeto de análise é a dimensão subjetiva dos direitos fundamentais e quando o foco examinado é a sua dimensão objetiva; (3) eventuais referências genéricas à "discricionariedade da competência administrativa em matéria de direitos fundamentais" podem subverter o verdadeiro significado dessa categoria jurídica, convertendo-a em uma escusa-coringa do Poder Público para acobertar omissões arbitrárias; (4) embora sob um prisma abstrato a explanação acima possa parecer correta, na realidade concreta a eficácia irradiante derivada da vertente objetiva dos direitos fundamentais reduz sobremaneira a discricionariedade administrativa, podendo chegar a suprimi-la a ponto de tornar vinculada a competência da Administração.

O desenvolvimento das duas primeiras ideias tem o propósito de demonstrar, no Tópico 4, que, por força do direito do cidadão à tutela administrativa efetiva espontânea, integral e igualitária - de sua esfera jurídica, a discricionariedade do Poder Público sofre, na seara dos direitos fundamentais, intensas limitações que advêm da dimensão objetiva de tais direitos, a qual impõe à Administração o dever de remover todos os entraves existentes e criar todas as condições necessárias para proporcionar a sua máxima satisfação, e de interpretar todo o ordenamento jurídico da maneira mais apropriada à realização ótima dos valores subjacentes aos direitos fundamentais.

\section{A discricionariedade administrativa em relação às dimensões subjetiva e objetiva dos direitos fundamentais: aspectos distintivos}

A primeira questão que há de ser sublinhada é a distinção entre dois âmbitos nos quais se manifesta a discricionariedade da Administração Pública em matéria

particular, se a ele está se atribuindo um direito subjetivo. A questão reporta-se, então, ao tema das competências discricionárias: se a norma deixa para a própria Administração a possibilidade de apreciar se, quando e como ela deverá agir, ao cidadão falece o poder de exigir esse ou aquele comportamento administrativo, pois ele não ostenta um direito público subjetivo. Apenas quando a norma fixa previamente o conteúdo do ato que se impõe à Administração, ditando-lhe de antemão o que, o como ou o quando é conveniente e oportuno fazer-se, haverá uma competência vinculada e, por conseguinte, exsurgirá um direito subjetivo oponível ao Estado. Só aí o indivíduo poderá exigir a atuação administrativa. Nesse sentido: BONNARD, Roger. Les droits publics subjectifs des administrés. Revue du droit public et de la science politique en France et a l' etranger, Paris, v. 49, p. 695-728, 1932, p. 712. 
de direitos fundamentais: (2.1) a seara das competências administrativas relativas à satisfação da dimensão subjetiva dos direitos fundamentais; (2.2) o campo das competências administrativas referentes à implementação da dimensão objetiva de tais direitos.

\subsection{Discricionariedade administrativa na seara da dimensão subjetiva dos direitos fundamentais}

Um dos possíveis setores de análise da discricionariedade administrativa em matéria de direitos fundamentais é o das competências públicas que tenham por finalidade atender à dimensão subjetiva de tais direitos. O elemento "provocação subjetiva" é o que caracteriza essas situações: um cidadão ou um grupo de pessoas exige da Administração que ela se comporte de determinada maneira, positiva ou negativa, para respeitar, proteger ou promover uma pretensão jurídica sua, à qual o sistema constitucional atribuiu o status de direito fundamental. São hipóteses que se apresentam no marco de uma relação jurídico-administrativa bem delineada, em que figuram: (i) um sujeito ativo (o titular do direito fundamental); (ii) um sujeito passivo (o Estado, titular da obrigação de cumprir a prestação correspondente); (iii) uma pretensão jurídica, conferida ao sujeito ativo, que Ihe permite exigir do sujeito passivo a observância de uma obrigação de cunho positivo ou negativo. Nesses casos, a competência administrativa para atender à pretensão do titular do direito pode ser integralmente vinculada ou conter elementos discricionários.

Hipóteses de competências administrativas vinculadas podem ser exemplificadas com alguns conteúdos específicos dos direitos fundamentais à previdência social, educação e liberdade de crença religiosa. 0 direito à aposentadoria voluntária dos servidores públicos, que traduz parcela do conteúdo do direito social à previdência (art. 6ํ, CF), é assegurado pelo art. 40, §1ํ, III, da Constituição. 0 agente que cumprir os requisitos ali descritos fará jus à concessão dos proventos oriundos de sua aposentação. Uma vez atendidas as exigências do comando normativo, não há espaços para a Administração deliberar sobre a conveniência ou oportunidade de aposentar o indivíduo. A competência administrativa que corresponde a esse direito é, portanto, vinculada. O mesmo se diga sobre o direito do cidadão ao acesso gratuito aos serviços públicos de educação básica, que englobam os níveis que vão desde educação infantil até o ensino médio. 0 art. 208, I, da CF prevê que a educação básica é obrigatória e gratuita, e o §1ํ do mesmo artigo, ao atestar que a pretensão de acesso a esses serviços é um “direito público subjetivo”, buscou reforçar o caráter vinculado e não discricionário da 
competência administrativa para prestá-los. Em terceiro lugar, citem-se os direitos fundamentais à liberdade de crença religiosa e a não ser privado de direitos por esse motivo (art. 5o, VI e VIII, CF). Sua tutela pode ser pleiteada ao Estado pelo indivíduo que pretenda, por razões religiosas, eximir-se de prestar o serviço militar obrigatório. Por força do que dispõem o art. 5, VI e VIII e o art. 143, §1ํ da CF, é vinculada a competência administrativa para conceder o pedido do cidadão de não servir militarmente às Forças Armadas e, em vez disso, prestar os serviços alternativos a que se referem esses dispositivos constitucionais. ${ }^{3}$ Inexiste margem de apreciação para que a Administração possa decidir se irá respeitar ou não a dimensão subjetiva do direito fundamental em questão: não Ihe é facultado verificar se há conveniência ou oportunidade no deferimento do pleito que Ihe foi dirigido.

De outra banda, é distinta a hipótese em que ao exercício da dimensão subjetiva do direito fundamental corresponde uma competência administrativa discricionária. Nessa situação, o ordenamento jurídico assegura à Administração Pública certo espaço de decisão, dentro dos limites fixados pelo direito positivo, para aferir se é conveniente e oportuno atender integralmente à pretensão do titular do direito. Sobre o tema, refira-se aos direitos fundamentais à liberdade de reunião e à moradia.

O primeiro abriga-se no art. 5ำ XVI, da CF com a seguinte redação: “Todos podem reunir-se pacificamente, sem armas, em locais abertos ao público, independentemente de autorização, desde que não frustrem outra reunião anteriormente convocada para o mesmo local, sendo apenas exigido prévio aviso à autoridade competente". Esse dispositivo constitucional empresta à Administração a competência discricionária para permitir ou não o pleno exercício da dimensão subjetiva de tal direito fundamental, pois a ela incumbe verificar, após ter sido avisada sobre a intenção de certo grupo de reunir-se no local informado: (i) se a reunião prejudicará outra que já estava anteriormente prevista para ocorrer no mesmo lugar; (ii) se a reunião se destina deliberadamente a fins ilícitos (v.g., manifestação de racismo); (iii) se a sua realização é perigosa para a integridade física dos indivíduos por conta do número excessivo de participantes que estarão presentes, simultaneamente, em um espaço público de pequenas dimensões espaciais; (iv) se é prejudicial a obstrução excessiva do livre trânsito no local onde se pretende realizar a reunião (v.g., via de acesso ao setor de emergência de um hospital); entre outros fatores. ${ }^{4} \mathrm{O}$ simples fato de o grupo comunicar ao Estado que irá se

3 A regulamentação de tais serviços é levada a efeito pela Lei no 8.239/91, a qual "regulamenta o art. $143, \S \S 1^{\circ}$ e $2^{\circ}$, da Constituição Federal, que dispõem sobre a prestação de Serviço Alternativo ao Serviço Militar Obrigatório".

4 Sobre as hipóteses de restrição da liberdade de reunião e os diversos critérios a serem observados para que o Poder Público possa limitá-la licitamente, inclusive com o desenvolvimento de alguns dos exemplos 
reunir em certo lugar, como se vê, não garante que a dimensão subjetiva do direito à liberdade de reunião haverá de ser integralmente exercitada por seus titulares e respeitada pelo Poder Público.

Em relação ao direito fundamental à moradia, ele se encontra arrolado no art. 6o da Constituição entre os direitos sociais. Contudo, o constituinte não especificou detalhadamente o modo de exercício das incumbências administrativas voltadas ao cumprimento de sua dimensão subjetiva. Dentre as competências comuns distribuídas à União, aos Estados, ao Distrito Federal e aos Municípios, o art. 23, IX, da Constituição da República determina que recai sobre todos eles o dever de "promover programas de construção de moradias e a melhoria das condições habitacionais e de saneamento básico". O texto constitucional, por si só, não fixou os critérios para lograr acesso às moradias por eles criadas, os parâmetros para melhorar as condições habitacionais da população, os requisitos necessários para que cada sujeito possa postular individualmente a concessão de uma prestação dessa natureza, entre tantos outros aspectos. Há, pois, certa discricionariedade da Administração para definir todos esses pontos, em consonância com as outras necessidades também urgentes do povo brasileiro. Isso não quer dizer, como se verá mais à frente, que o Poder Público deva cumprir o art. 23, IX e a dimensão subjetiva do direito à moradia quando quiser, como quiser, se quiser e em favor de quem quiser. ${ }^{5}$ Em relação a diversos elementos, essa discricionariedade pode vir a ser reduzida a zero até tornar-se vinculada, como nos casos que dizem respeito ao mínimo existencial. ${ }^{6}$ Mas naquilo que desborda o conteúdo desse mínimo, as competências administrativas destinadas a satisfazer a perspectiva subjetiva do direito à moradia contam com algumas porções de discricionariedade.

Todos os exemplos até aqui apontados envolvem circunstâncias em que o titular do direito fundamental provoca a Administração Pública para exigir o seu respeito, a sua proteção ou a sua promoção. Porém, a eficácia jurídica da aplica-

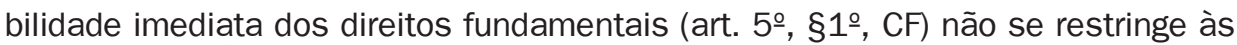
hipóteses relativas à dimensão subjetiva desses direitos. Ela impõe também que

acima colacionados, ver: ALMEIDA, Fernando Dias Menezes de. Liberdade de reunião. São Paulo: Max Limonad, 2001. p. 231 et seq.

5 VALLE, Vanice Regina Lírio do. Judicial adjudication in housing rights in Brazil and Colombia: a comparative perspective. Revista de Investigações Constitucionais, Curitiba, v. 1, n. 2, p. 67-102, maio/ago. 2014. Disponivel em: <http://dx.doi.org/10.5380/rinc.v1i2.40511>.

6 Sobre o tema do mínimo existencial, ver: SARLET, Ingo Wolfgang; ZOCKUN, Carolina Zancaner. Notas sobre o mínimo existencial e sua interpretação pelo STF no âmbito do controle judicial das políticas públicas com base nos direitos sociais. Revista de Investigações Constitucionais, Curitiba, v. 3, n. 2, p. 115-141, maio/ago. 2016. Disponivel em: <http://dx.doi.org/10.5380/rinc.v3i2.46594>; HACHEM, Daniel Wunder. Mínimo existencial y derechos económicos y sociales: distinciones y puntos de contacto a la luz de la doctrina y jurisprudencia brasileñas. Revista Eurolatinoamericana de Derecho Administrativo, Santa Fe, v. 1, n. 1, p. 93-138, ene./jun. 2014. Disponível em: <www.dx.doi.org/10.14409/rr.v1i1.4609>. 
a Administração, para manter-se dentro das balizas jurídico-constitucionais, deverá implementar a dimensão objetiva dos direitos fundamentais, agindo de ofício para a sua promoção otimizada. E nesse âmbito também ganha relevância o tema das competências administrativas discricionárias.

\subsection{Discricionariedade administrativa no campo da dimensão objetiva dos direitos fundamentais}

Outro campo de análise, distinto do anterior, consiste nos limites da discricionariedade de que dispõe a Administração para dar execução à dimensão objetiva dos direitos fundamentais. Aqui não está em jogo a existência de um pedido ou de uma exigência do titular do direito perante o Poder Público. 0 foco, quando se trata desse assunto, consiste nos deveres que incumbem à Administração, independentemente de qualquer provocação subjetiva, de: (i) criar as condições necessárias para que os direitos fundamentais possam ser fruídos de maneira integral e universalizada, removendo os obstáculos que impeçam o seu exercício real e efetivo (deveres autônomos de proteção); (ii) interpretar todo o ordenamento jurídico constitucional e infraconstitucional à luz do conteúdo valorativo inerente a esses direitos (eficácia irradiante); (iii) proteger os titulares dos direitos fundamentais contra si mesmos (valor comunitário). ${ }^{7}$ Importa explorar as consequências jurídicas do primeiro neste item (2.2) e, do segundo, no Item 4, infra.

Relembre-se que um dos traços de maior importância da vertente objetiva dos direitos fundamentais - deveres autônomos de proteção - é a obrigação que ela impõe à Administração de agir preventivamente, seja para impedir que outros sujeitos privados agridam tais direitos, seja para fazer com que a sua fruição pelos seus titulares seja real e efetiva (e não apenas uma promessa abstrata). Dos enunciados que veiculam direitos fundamentais decorre uma imposição autônoma, dirigida à Administração Pública, de instituir: (i) disposições normativas que disciplinem, mediante a fixação de critérios, a forma como serão exercidos os direitos fundamentais; (ii) aparatos organizacionais que possibilitem o seu exercício no mundo dos fatos; (iii) previsões em atos administrativos normativos que regulem meios de proteção dos bens jurídicos jusfundamentais contra ofensas advindas de outros particulares; (iv) instrumentos e regras procedimentais que facilitem a exigibilidade dos direitos fundamentais perante o Poder Público; (v)

Para um aprofundamento acerca da dimensão objetiva dos direitos fundamentais, ver: HACHEM, Daniel Wunder. A dupla titularidade (individual e transindividual) dos direitos fundamentais econômicos, sociais, culturais e ambientais. Revista de Direitos Fundamentais e Democracia, v. 14, n. 14, Curitiba, p. 618-688, jul./dez. 2013. 
ações e serviços de prestação de utilidades ou comodidades materiais que sejam necessários à satisfação dos direitos fundamentais.

Convém retomar alguns dos exemplos de direitos mencionados no ponto (2.1) para demonstrar a diferença que existe no tema da discricionariedade administrativa quando se está investigando a dimensão subjetiva ou a dimensão objetiva dos direitos fundamentais. Afirmou-se ali que é vinculada a competência administrativa para conceder as pretensões jurídicas jusfundamentais ligadas à aposentadoria voluntária dos servidores públicos (art. 6으 c/c art. 40, §1ํㅡ, III), ao acesso gratuito aos serviços públicos de educação básica (art. 208, I e §1ํㅡ, CF) e à liberdade de crença religiosa conjugada com o direito a não ser privado de direitos por esse motivo (art. 5ํ, VI e VIII, CF). A referência foi feita à dimensão subjetiva desses direitos. Mas quando se tiver como objeto de análise as competências administrativas destinadas a realizar a sua dimensão objetiva (mais especificamente no que diz respeito aos deveres autônomos de proteção), serão elas vinculadas ou discricionárias?

As previsões do art. 6으 (direito social à previdência) e do art. 40, §1ํㅡ, III (aposentadoria voluntária dos servidores), mesmo que o titular do direito em apreço não o exija do Estado, obrigam a Administração Pública a criar normas que estabeleçam critérios para a contagem do tempo de contribuição, órgãos que prestem eficientemente o serviço público de previdência social, mecanismos procedimentais para que os pedidos tramitem perante o órgão competente e sejam analisados em prazo razoável, entre tantas outras medidas. São deveres objetivos que traduzem competências administrativas. Embora a competência específica para conceder o direito quando ele é postulado pelo seu titular (dimensão subjetiva) seja vinculada, a competência genérica para prestar o serviço conta com diversas porções de discricionariedade. É à Administração Pública que incumbe verificar, por exemplo, se ele será prestado de forma centralizada, pela Administração direta ou se será apresentado projeto de lei para criar uma entidade que venha a integrar a Administração indireta para fornecê-lo de maneira descentralizada. Todavia, por força da aplicabilidade imediata dos direitos fundamentais (art. 5으, §1ํ, CF), ela não detém margem de apreciação para decidir se vai prestar ou não o serviço público de previdência social, nem para optar quando irá fornecêlo. Ela sempre deverá fazê-lo e está compelida a isso desde a promulgação da Constituição, instante a partir do qual os direitos fundamentais nela albergados se tornaram imediatamente aplicáveis. Esses são aspectos vinculados da competência administrativa destinada a implementar a dimensão objetiva do direito fundamental à aposentadoria, ainda que ela contenha outros componentes que ostentem natureza discricionária.

O mesmo se pode dizer quanto aos outros direitos antes aventados. É vinculada a competência administrativa para conceder o acesso do cidadão ao serviço gratuito 
de educação básica (dimensão subjetiva). Mas a competência que a Administração recebe para, espontaneamente, criar escolas públicas, aumentar o número de vagas e o espaço físico das existentes, abrir concurso para nomear novos professores, etc. - deveres oriundos da perspectiva objetiva do direito fundamental à educação - contém parcelas de discricionariedade. Quanto a esses assuntos, ela pode escolher os melhores meios e as formas mais idôneas para prestar adequadamente o serviço, mas não Ihe cabe optar se vai ou não oferecê-lo, nem quando irá fazê-lo. Cuida-se de um dever permanente. Mencione-se, ainda sobre o direito à educação, outro segmento que integra o seu conteúdo: o direito do educando a um atendimento proporcionado mediante programas suplementares de material didático escolar, transporte, alimentação e assistência à saúde (art. 208, VII, CF). À Administração incumbe, obrigatoriamente, desenvolver tais programas com o escopo de atingir as finalidades narradas no comando normativo (dimensão objetiva). Não the compete escolher entre promovê-los ou não. No entanto, ela desfruta de um espaço discricionário para selecionar quais são as maneiras mais oportunas e convenientes de implementá-los.

É também vinculada a competência administrativa para deferir o pedido de prestação de serviços alternativos em substituição ao serviço militar obrigatório quando o indivíduo fundamentar sua pretensão no direito fundamental à liberdade de crença religiosa (dimensão subjetiva). Entretanto, o dever da Administração de eleger quais serão os serviços alternativos que poderão ser desempenhados pelos titulares desse direito e optar entre quais atividades de caráter administrativo, assistencial, filantrópico ou produtivo serão postas à disposição dos particulares revela-se como uma competência revestida de aspectos discricionários. A Lei no 8.239/91 fixa alguns parâmetros, a partir dos quais o ente administrativo deverá verificar, discricionariamente, quais ações são mais convenientes e oportunas para o Estado brasileiro. Logo, não cabe à Administração deliberar se vai cumprir esses deveres objetivos de agir, nem quando irá atendê-los. Tais elementos serão sempre vinculados.

Daí se depreende que, em relação à dimensão objetiva dos direitos fundamentais, ligadas aos deveres da Administração Pública de agir espontaneamente em prol de sua máxima efetivação, as competências administrativas $\mathrm{x}$ a Administração pode - em alguns casos com mais intensidade, outros com menos - escolher quais ações serão priorizadas, com o investimento de quantias mais elevadas de recursos financeiros, os meios que serão empregados para implementá-las e as formas jurídicas que serão utilizadas para tanto. Aí residirá a discricionariedade. Porém, quanto a agir ou não agir e quanto ao momento de adotar medidas coletivas para proporcionar a realização dos direitos fundamentais, não haverá discricionariedade alguma: o dever de atuar sempre estará presente e deverá ser cumprido permanentemente, isto é, a todo o momento. 
Em suma: quando o tema em debate for a discricionariedade da Administração Pública em matéria de direitos fundamentais, a resposta quanto à natureza vinculada ou discricionária da competência administrativa voltada à satisfação do direito depende do esclarecimento prévio de duas questões: (i) a qual dimensão do direito fundamental se está aludindo (subjetiva ou objetiva); (ii) a quais aspectos da competência se está referindo.

\section{A referência genérica à "discricionariedade da competência administrativa em matéria de direitos fundamentais": 0 risco do joker do Poder Público para acobertar omissões arbitrárias}

O segundo ponto que reclama atenção consiste na crítica que deve ser feita quanto às referências genéricas à "discricionariedade da competência administrativa" em matéria de direitos fundamentais. Não se pode aludir genericamente à "discricionariedade da Administração" para adotar medidas voltadas à realização dos direitos fundamentais. Faz-se imperioso, em cada situação concreta, verificar se havia de fato um espaço de deliberação outorgado pelo direito para que ela pudesse optar sobre como, quando, com quais meios e se deveria agir. Do contrário, a noção de discricionariedade perde a sua razão de ser. Menções dessa natureza acabam por distorcer o significado dessa categoria jurídica, transformando-a em um argumento utilizado como um joker pelo Poder Público, com o fim de encobrir a antijuridicidade de suas posturas omissivas agressivas aos direitos fundamentais. Daí a necessidade de examinar o tema com cautela. A discricionariedade, conforme assevera Jaime Rodríguez-Arana Muñoz, "é o cavalo de Troia do Direito Público pela simples razão de que seu uso objetivo nos situa no interior do Estado de Direito e seu exercício abusivo nos leva ao mundo da arbitrariedade e do autoritarismo". 8

Como álibi para justificar a inefetividade dos direitos ora discutidos, costuma-se dizer que, muito embora o ordenamento jurídico outorgue competência ao Poder Executivo para concretizar os direitos fundamentais sociais, essa competência seria de cunho discricionário, permitindo ao administrador público optar pelo momento de agir e pelos meios a serem utilizados para o alcance dessa finalidade. E essa explicação acaba sendo empregada justamente nas hipóteses em que a passividade da Administração já não se encontra mais dentro do círculo

8 RODRÍGUEZ-ARANA MUÑOZ, Jaime. Direito fundamental à boa Administração Pública. Trad. Daniel Wunder Hachem. Belo Horizonte: Fórum, 2012, p. 158. 
de legitimidade delimitado pela Constituição e pela lei, isto é, em situações nas quais a conduta estatal já ultrapassou as fronteiras da discricionariedade e adentrou as raias da arbitrariedade. ${ }^{9}$

Um caso concreto, apreciado por três instâncias do Poder Judiciário brasileiro, bem ilustra o que se está a dizer. Pede-se licença para expor de forma detalhada algumas passagens do processo com o fito de demonstrar que o argumento genérico da discricionariedade administrativa, quando usado no campo dos direitos fundamentais sociais, pode implicar fortes distorções de sua autêntica significação jurídica.

No Município de Cambará, situado no Estado do Paraná, havia um número crescente de crianças e adolescentes em estado de abandono ou sem possibilidade de reintegração familiar. O Ministério Público ajuizou ação civil pública, postulando que a municipalidade fosse condenada a destinar um imóvel para a instalação de um abrigo para menores carentes, com recursos materiais e humanos essenciais, e a elaborar programas de proteção à criança e aos adolescentes em regime de abrigo. A Constituição brasileira, como se sabe, assegura expressamente no art. 6o os direitos sociais à moradia e à assistência aos desamparados. No art. 227, a Lei Maior determina que é “dever da família, da sociedade e do Estado assegurar à criança, ao adolescente e ao jovem, com absoluta prioridade, o direito à vida, à saúde, à alimentação, à educação, ao lazer, à profissionalização, à cultura, à dignidade, ao respeito, à liberdade e à convivência familiar e comunitária, além de colocá-los a salvo de toda forma de negligência, discriminação, exploração, violência, crueldade e opressão". É inquestionável que o constituinte estabeleceu, como decisão política fundamental, que a atenção estatal aos direitos fundamentais da criança e do adolescente não é uma mera faculdade da Administração. A redação dessa disposição constitucional não deixa dúvidas: ela fala em absoluta prioridade. A existência de uma vasta quantidade de menores carentes e sem abrigo no município certamente implica negligência estatal, vedada pelo art. 227, bem como desrespeito aos diversos direitos fundamentais ali proclamados.

O caso em tela é interessante porque não só o texto constitucional foi enfático ao impor a obrigação de conferir total prioridade às ações relativas à proteção da criança e do adolescente, como também havia previsões específicas na legislação federal e municipal que reduziam ainda mais a margem de apreciação subjetiva da Administração Pública nessa seara. O Estatuto da Criança e do Adolescente (Lei

9 Nunca é demais lembrar, conforme ressalta Tomás-Ramón Fernández, que discricionariedade e arbitrariedade não se confundem: são, muito pelo contrário, dois conceitos antagônicos (FERNÁNDEZ, TomásRamón. De la arbitrariedad de la Administración. 5. ed. Navarra: Thomson-Civitas, 2008, p. 81). 
Federal no 8.069/90) precisou o significado da expressão “prioridade" empregada pelo constituinte, estabelecendo no art. 4ํㅜㄹ parágrafo único, que “a garantia de prioridade compreende: a) primazia de receber proteção e socorro em quaisquer circunstâncias; b) precedência de atendimento nos serviços públicos ou de relevância pública; c) preferência na formulação e na execução das políticas sociais públicas; d) destinação privilegiada de recursos públicos nas áreas relacionadas com a proteção à infância e à juventude". 0 art. $7^{\circ}$ do mesmo diploma prevê, ainda, que "a criança e o adolescente têm direito a proteção à vida e à saúde, mediante a efetivação de políticas sociais públicas que permitam o nascimento e o desenvolvimento sadio e harmonioso, em condições dignas de existência". Além disso, a Lei Municipal no 907/90, ao disciplinar a política municipal de atendimento dos direitos da criança e do adolescente em Cambará, estipulou que o município "poderá criar os programas e serviços" (art. 4ํ) referentes à "política e programas de assistência social, em caráter supletivo" e "serviços especiais" (art. $2^{\circ}$, II e III).

O juízo de primeira instância negou o pedido de liminar e julgou improcedente o pedido do autor, ancorando-se no argumento de que "mandar o Réu destinar um imóvel para a construção de abrigo e destinar equipe especializada para mantê-lo, na atual conjuntura, certamente não atenderia, consoante pretende o Ministério Público, à sociedade, pois a Prefeitura já destina parte considerável de sua verba orçamentária aos menores carentes, não tendo condições de ampliar essa ajuda, que, diga-se de passagem, é sua atribuição e está sendo cumprida" (fls. 116 dos autos). Acolheu-se o argumento do Poder Público de que o município já apoiava entidades beneficentes de assistência social, repassando-lhes regularmente verbas orçamentárias e fornecendo condições para o seu funcionamento, razão pela qual o Poder Executivo estava "cumprindo sua missão dentro das possibilidades do município" (fls. 42 dos autos). ${ }^{10}$ Ainda que o ente municipal não possuísse um abrigo sequer dedicado a essa finalidade, entendeu o juiz de primeiro grau que o fato de ele estar prestando auxílio público às entidades da sociedade civil organizada significava que os deveres do município estavam sendo adimplidos.

O Ministério Público interpôs recurso de apelação, ao qual o Conselho da Magistratura do Tribunal de Justiça do Estado do Paraná, por unanimidade de votos, negou provimento. Consignou-se no acórdão que "não se pode obrigar a municipalidade a atender àquelas medidas - destinar um imóvel para instalação de um abrigo, dando-Ihe recursos materiais e humanos essenciais -, quer porque

10 Os trechos entre aspas e a indicação das folhas dos autos foram extraídos do corpo do Acórdão n 7.910 proferido pelo Tribunal de Justiça do Estado do Paraná, cuja íntegra encontra-se disponível no sítio do Ministério Público paranaense no seguinte endereço: <http://www2.mp.pr.gov.br/cpca/telas/ca_igualdade_14_4_1_1. php>. Acesso em 10 out. 2013. 
ela demonstrou não ter, no momento, condições para efetivar a obra pretendida, sem prejudicar as demais atividades do município, quer porque, face ao princípio da discricionariedade, de que goza o Chefe do Executivo Municipal, este tem total liberdade para eleger as obras prioritárias a serem construídas". 0 art. 227 da Constituição determina que o Estado deverá atribuir absoluta prioridade à proteção da dignidade da criança e do adolescente, e, mesmo assim, o Tribunal de Justiça entendeu que o prefeito goza de "total liberdade para eleger as obras prioritárias a serem construídas". A frase ora grifada em itálico consta, inclusive, da ementa da decisão. ${ }^{11}$ Se a municipalidade não tinha condições financeiras para, naquele momento, construir a obra pleiteada, parece estar claro que, na definição de seu orçamento, não foi dada a absoluta prioridade à tutela da criança e do adolescente, tal como determina a Constituição.

O parquet não desistiu e chegou até o Superior Tribunal de Justiça pela via do recurso especial. A Corte manteve integralmente a decisão do Tribunal de Justiça do Estado do Paraná, decidindo que, "com fulcro no princípio da discricionariedade, a Municipalidade tem liberdade para, com a finalidade de assegurar o interesse público, escolher onde devem ser aplicadas as verbas orçamentárias e em quais obras deve investir. Não cabe, assim, ao Poder Judiciário interferir nas prioridades orçamentárias do município e determinar a construção de obra especificada". ${ }^{12}$ É interessante que o acórdão, antes de chegar a essa conclusão, cita trechos da obra de Celso Antônio Bandeira de Mello, os quais, ao que tudo indica, apontam para o sentido diametralmente oposto ao que trilhou o Tribunal. Vejase: “A discricionariedade existe, única e tão-somente para proporcionar em cada caso a escolha da providência ótima, isto é, daquela que realize superiormente o interesse público almejado pela lei aplicanda. Não se trata, portanto, de uma liberdade para a Administração decidir a seu talante, mas para decidir-se de modo que torne possível o alcance perfeito do desiderato normativo". ${ }^{13}$

11 AÇÃO CIVIL PÚBLICA. PRECEITOS COMINATÓRIOS. OBRIGAÇÃO DE FAZER. INSTALAÇÃO DE ABRIGO E ELABORAÇÃO DE PROGRAMAS DE PROTEÇÃO À CRIANÇA E AOS ADOLESCENTES EM REGIME DE ABRIGO. IMPROCEDÊNCIA. DECISÃO CONFIRMADA. 1. Em razão do princípio da discricionariedade, que rege a atividade do Executivo, este "goza de total liberdade para eleger as obras prioritárias a serem construídas". 2. Assim, não podendo a Administração Pública destinar imóvel, para instalação de abrigo de menores, dotando-o de recursos materiais e humanos, sem prejuízo das demais atividades municipais, improcede a ação proposta, destinada a obrigar o Município à efetivação daquela obra (BRASIL. Tribunal de Justiça do Estado do Paraná. Recurso de Apelação de Menores no 105-9. Acórdão no 7910. Relator Des. Accácio Cambi. Conselho da Magistratura. Julgado em 09.02.1998. Disponível em: <http://www2.mp.pr.gov.br/ cpca/telas/ca_igualdade_14_4_1_1.php>. Acesso em 10 out. 2013).

12 BRASIL. Superior Tribunal de Justiça. Recurso Especial o 208.893/PR. Relator Min. Franciulli Netto. Segunda Turma. Julgado em 19.12.2003. DJ 22.03.2004.

13 A referência indicada no acórdão foi: MELLO, Celso Antônio Bandeira de. Curso de Direito Administrativo. 15. ed. São Paulo: Malheiros, 2003, p. 399. O excerto consta da página 440 da $30^{a}$ edição, de 2013, a qual tem sido utilizada no presente trabalho. 
As lições do referido jurista, ao contrário da posição manifestada pelo STJ, bem alertam para a impossibilidade de se creditar na ideia de discricionariedade uma ampla liberdade do administrador para agir a seu bel-prazer, desviando-se da rota prefixada pelo ordenamento jurídico. Aliás, na obra do autor, logo na frase seguinte àquela que foi citada no acórdão, ele adverte que, "para verificar se o ato administrativo se conteve dentro do campo em que realmente havia discrição, isto é, no interior da esfera de opções legítimas, é preciso atentar para o caso concreto" ${ }^{14}$ E na situação concreta ora discutida, tudo leva a crer que a Administração já não estava mais dentro da órbita das escolhas legítimas, pois se recusou a dar "preferência na formulação e na execução das políticas sociais públicas" relativas à criança e ao adolescente e a fornecer "destinação privilegiada de recursos públicos nas áreas relacionadas com a proteção à infância e à juventude”, tal como se exige no art. 4ํㅡㄹ parágrafo único, alíneas $c$ e $d$ da Lei no 8.069/90. Em outras palavras: o município negou-se a priorizar uma ação à qual o art. 227 da Constituição determinou seja dada absoluta prioridade.

A posição do Poder Judiciário nas três instâncias em que tramitou o processo ${ }^{15}$ - juiz de primeiro grau, Tribunal de Justiça do Estado do Paraná e Superior Tribunal de Justiça - é incompreensível sob o prisma do perfil contemporâneo do direito administrativo e do controle judicial da Administração Pública, iluminados pela dignidade da pessoa humana e pelos direitos fundamentais. ${ }^{16} \mathrm{E}$ especialmente nessa situação específica, uma vez que, no cenário dos direitos humanos, o direito à moradia desfruta de um papel privilegiado, pois se revela como um elemento imprescindivel para assegurar uma vida digna. ${ }^{17} \mathrm{Sim}$, a Administração goza de competência discricionária para eleger onde devem ser aplicados os recursos orçamentários e em quais obras deve investir, mas, consoante à lição de Bandeira de Mello transcrita no próprio acórdão do STJ, isso somente pode ser feito dentro

14 MELLO, Celso Antônio Bandeira de. Curso de Direito Administrativo. 30. ed. São Paulo: Malheiros, 2013, p. 440.

15 O Ministério Público interpôs também recurso extraordinário perante o Supremo Tribunal Federal. Contudo, a Corte negou seguimento à manifestação recursal intentada, sob o argumento de que para rever a decisão do Tribunal de Justiça do Estado do Paraná seria necessário reexaminar fatos e provas, o que é vedado em sede de recurso extraordinário consoante a Súmula o 279 do STF. Para acessar a íntegra da decisão monocrática, ver: BRASIL. Supremo Tribunal Federal. Recurso Extraordinário no 423.662. Relator Min. Joaquim Barbosa. Julgado em 04.12.2009. Publicado em DJe-237, divulgado em 17.12.2009, publicado em 18.12.2009.

16 Sobre os impactos do princípio da dignidade da pessoa humana no Direito Administrativo, ver: GONZÁLEZ PÉREZ, Jesús. La dignidad de la persona y el Derecho Administrativo. A\&C - Revista de Direito Administrativo \& Constitucional, no 29, Belo Horizonte, Fórum, p. 11-35, jul./set. 2007; e DI PIETRO, Maria Sylvia Zanella. Direito administrativo e dignidade da pessoa humana. A\&C - Revista de Direito Administrativo \& Constitucional, № 52, Belo Horizonte, Fórum, p. 13-33, abr./jun. 2013.

17 MASSIMINO, Leonardo F. Los derechos humanos y el derecho a la vivienda: los critérios judiciales. A\&C - Revista de Direito Administrativo \& Constitucional, № 51, Belo Horizonte, Fórum, p. 29-47, jan./ mar. 2013, p. 46. 
dos limites que são impostos pela lei e pela Constituição. E o dever do Estado de garantir ao menos o núcleo essencial do direito fundamental à moradia é uma competência vinculada, pois ele integra o direito ao mínimo existencial, que há de ser aplicado como uma regra, em termos definitivos, e não prima facie. ${ }^{18}$ Pode a Administração escolher os meios mais adequados para tanto, mas está fora de sua margem de escolhas legítimas a decisão sobre atuar ou não atuar nessa área. A omissão, portanto, é contrária ao ordenamento jurídico e já se situa no solo da arbitrariedade, não mais no da discricionariedade.

O caso ora examinado mostra o efeito pernicioso das alusões genéricas à discricionariedade administrativa na temática dos direitos fundamentais. Percebase como é fácil citar a teoria em termos gerais e, na prática, afastar-se dela com grande tranquilidade. E o recurso a essa categoria jurídica para justificar a inação do Poder Público em matéria de direitos sociais não é algo exclusivo da decisão supracitada, estando presente também em outros julgados que envolvem os direitos à saúde, ${ }^{19}$ à educação, ${ }^{20}$ à moradia e ao meio ambiente, ${ }^{21}$ à acessibilidade das pessoas com deficiência física, ${ }^{22}$ entre outros. Com isso, o significado da

18 La fundamentación jurídica para llegarse a esa conclusión fue desarrollada en otro estudio: HACHEM, Daniel Wunder. Mínimo existencial y derechos económicos y sociales: distinciones y puntos de contacto a la luz de la doctrina y jurisprudencia brasileñas. Revista Eurolatinoamericana de Derecho Administrativo, Santa Fe, v. 1, n. 1, p. 93-138, ene./jun. 2014. Disponivel em: <www.dx.doi.org/10.14409/rr.v1i1.4609>.

19 CONSTITUCIONAL - ADMINISTRATIVO - AÇÃO CIVIL PÚBLICA - PODER DISCRICIONÁRIO DA ADMINISTRAÇÃO - EXERCÍCIO PELO JUIZ - IMPOSSIBILIDADE - PRINCÍPIO DA HARMONIA ENTRE OS PODERES. O juiz não pode substituir a Administração Pública no exercício do poder discricionário. Assim, fica a cargo do Executivo a verificação da conveniência e da oportunidade de serem realizados atos de administração, tais como, a compra de ambulâncias e de obras de reforma de hospital público. (...) (BRASIL. Superior Tribunal de Justiça. Agravo Regimental no Recurso Especial no 252.083/RJ. Relatora Min. Nancy Andrighi. Segunda Turma. Julgado em 27.06.2000. DJ 26.03.2001).

20 (...) 1. O ensino fundamental é prioritário, mas ao Estado impõe-se a obrigação de prestar o ensino infantil, cabendo ao Município incluí-lo na sua política educacional. 2. Aos órgãos públicos só pode ser imposto pelo Judiciário obrigação de fazer que importe gastos imediatos, fora do normal orçamento, em se tratando de urgentes necessidades, quando em perigo a vida. 3. Com referência à educação, dever estatal de urgência, mas passível de espera razoável, a imposição da obrigação de fazer pode aguardar o planejamento específico. (...) (BRASIL. Superior Tribunal de Justiça. Recurso Especial no 782.196/SP. Relatora Min. Eliana Calmon. Segunda Turma. Julgado em 13.03.2007. DJ 22.03.2007).

21 (...) 2. Impossibilidade do juiz substituir a Administração Pública determinando que obras de infra-estrutura sejam realizadas em conjunto habitacional. Do mesmo modo, que desfaça construções já realizadas para atender projetos de proteção ao parcelamento do solo urbano. 3. Ao Poder Executivo cabe a conveniência e a oportunidade de realizar atos físicos de administração (construção de conjuntos habitacionais, etc.). o Judiciário não pode, sob o argumento de que está protegendo direitos coletivos, ordenar que tais realizações sejam consumadas. (...) 6 . As atividades de realização dos fatos concretos pela administração depende de dotações orçamentárias prévias e do programa de prioridades estabelecidos pelo governante. Não cabe ao Poder Judiciário, portanto, determinar as obras que deve edificar, mesmo que seja para proteger o meio ambiente. 7. Recurso provido (BRASIL. Superior Tribunal de Justiça. Recurso Especial no 169.876/SP. Relator Min. José Delgado. Primeira Turma. Julgado em 16.06.1998. DJ 21.09.1998).

22 RECURSO ORDINÁRIO. MANDADO DE SEGURANÇA. LICENÇA DE OBRAS DE MODIFICAÇÃO E REFORMA NO MORRO DA URCA E NO MORRO DO PÃO DE AÇÚCAR E LICENÇA PARA A INSTALAÇÃO DE ELEVADORES DESTINADOS A DEFICIENTES FÍSICOS. ALEGADA OMISSÃO DO PREFEITO DO MUNICÍPIO DO RIO DE JANEIRO. 
discricionariedade administrativa acaba sendo desvirtuado. Afinal, por qual motivo ela existe e continua operando no direito administrativo contemporâneo? Para que o administrador possa identificar no caso concreto quais são as melhores opções, dentro do espaço demarcado pelo ordenamento jurídico, para atender mais eficazmente aos objetivos subjacentes às disposições normativas constitucionais e infraconstitucionais. ${ }^{23}$ Se (i) a Constituição e a legislação obrigam o município a dar absoluta prioridade à promoção da dignidade da criança e do adolescente, investindo os recursos públicos preferencialmente nessa área; (ii) a municipalidade não possuía um abrigo sequer para menores carentes em situação de abandono; e (iii) o número de crianças nessa situação estava aumentando, questiona-se: a opção da Administração de se manter inerte estava dentro do seu círculo de escolhas legítimas? É evidente que não. A hipótese em debate é emblemática porque esse setor social foi o único em que o constituinte foi tão enfático a ponto de empregar a locução “absoluta prioridade”. Ou seja, se há demanda nessa seara, já não resta mais espaço de decisão para a Administração a respeito de nela investir ou não investir, pois as necessidades surgidas nesse campo desfrutam de preferência na pauta do Poder Público, por predeterminação do sistema normativo.

Enfim, o que se pretende grifar nesta oportunidade é que a discricionariedade não pode se converter em um mito jurídico, uma categoria descolada do verdadeiro propósito ao qual ela se destina. Se a discrição administrativa se trata de um mecanismo para garantir que a Administração irá empreender as melhores opções para atingir aos fins estampados na ordem jurídica, ${ }^{24}$ ela jamais pode ser invocada como fundamento para legitimar que o Poder Público permaneça inativo, deixando de empregar as medidas necessárias para dar concretude aos direitos fundamentais.

NÃO EVIDENCIADA A PRESENÇA DE SUPOSTO DIREITO LÍQÜIDO E CERTO. DISCRICIONARIEDADE DA MUNICIPALIDADE. NÃO-CABIMENTO DE INTERFERÊNCIA DO PODER JUDICIÁRIO NA ESPÉCIE. (...) com fulcro no princípio da discricionariedade administrativa e na supremacia do interesse público, a Municipalidade tem liberdade para decidir pela conveniência ou não da execução da obra. Como ensina Hely Lopes Meirelles, 'só o administrador, em contato com a realidade, está em condições de bem apreciar os motivos ocorrentes de oportunidade e conveniência na prática de certos atos (...). Só os órgãos executivos é que estão, em muitos casos, em condições de sentir e decidir administrativamente o que convém e o que não convém ao interesse coletivo'. Recurso ordinário improvido (BRASIL. Superior Tribunal de Justiça. Recurso Ordinário em Mandado de Segurança no 19.535/RJ. Relator Min. Franciulli Netto. Segunda Turma. Julgado em 01.09.2005. DJ 31.05.2006).

23 Conforme explica Celso Antônio Bandeira de Mello, “o administrador está (...) nos casos de discricionariedade, perante o dever jurídico de praticar, não qualquer ato dentro os comportados pela regra, mas, única e exclusivamente aquele que atenda com absoluta perfeição à finalidade da lei" (MELLO, Celso Antônio Bandeira de. Discricionariedade e controle jurisdicional. 2. ed. 8. tir. São Paulo: Malheiros, 2007, p. 33).

24 Nessa esteira, Luis Manuel Fonseca Pires destaca que, quando a norma jurídica outorga ao agente uma competência discricionária, "a escolha deve ser exercida, diante do caso concreto, pela melhor opção possivel à realização do interesse público” (PIRES, Luis Manuel Fonseca. Controle judicial da discricionariedade administrativa: dos conceitos jurídicos indeterminados às políticas públicas. 2. ed. Belo Horizonte: Fórum, 2013. p. 201). 


\section{Eficácia irradiante dos direitos fundamentais e redução da discricionariedade administrativa: preenchimento dos espaços de vazio normativo pela dimensão objetiva}

Uma vez tecidas as considerações acima expostas, impende verificar qual o efeito jurídico que a aplicabilidade imediata dos direitos fundamentais, insculpida no art. 5ำ $\S^{\circ}{ }^{\circ}$, da Constituição brasileira, produz sobre as hipóteses de discricionariedade administrativa. A proposição aqui defendida é a de que a eficácia irradiante decorrente da dimensão objetiva dos direitos fundamentais reduz significativamente as fronteiras da discricionariedade administrativa, podendo inclusive vir a eliminá-la, tornando vinculada a competência da Administração Pública.

A eficácia irradiante dos direitos fundamentais deriva da sua condição de valores essenciais de uma sociedade, característica que os confere o status de verdadeiras "bases da ordem jurídica da coletividade". ${ }^{25}$ Eles constituem "os pressupostos do consenso sobre o qual se deve edificar qualquer sociedade democrática", ${ }^{26}$ o que Ihes atribui um conteúdo legitimador das formas constitucionais do Estado de Direito. Por isso, os direitos fundamentais imprimem a substância axiológica que deve obrigatoriamente marcar um Estado Material de Direito, em que a mera existência de determinadas formas e procedimentos atinentes à organização do poder e às competências dos órgãos estatais não se afigura suficiente para a garantia da legitimidade estatal, tornando-se necessário fixar objetivos, parâmetros e limites da atividade do Estado, a partir dessa vinculação de cunho substancial. ${ }^{27}$

Assim, este reflexo da perspectiva objetiva dos direitos fundamentais se revela na proteção de determinados valores pela ordem jurídica, por meio de normas jusfundamentais, que se apresentam como faróis para a interpretação e orientação da compreensão das disposições normativas constitucionais e infraconstitucionais. Desse fato - de que as normas de direitos fundamentais albergam valores essenciais - deriva a obrigação de todos os Poderes Públicos de adotar a axiologia a eles subjacente como diretiva para a aplicação de toda e qualquer norma, legitimando juridicamente os atos estatais consonantes com esse conteúdo valorativo e inquinando de invalidade as ações que Ihe forem contrárias.

Ou seja: em virtude das características acima descritas, os direitos fundamentais irradiam o seu conteúdo jurídico-valorativo para todas as direções do

25 HESSE, Konrad. Elementos de Direito Constitucional da República Federal da Alemanha. Trad. Luís Afonso Heck. Porto Alegre: Sérgio Antonio Fabris, 1998, p. 239.

26 PÉREZ LUÑO, Antonio Enrique. Los derechos fundamentales. 9. ed. Madrid: Tecnos, 2007, p. 21.

27 SARLET, Ingo Wolfgang. A eficácia dos direitos fundamentais: uma teoria geral dos direitos fundamentais na perspectiva constitucional. 10. ed. Porto Alegre: Livraria do Advogado, 2010, p. 59 e 61. 
sistema normativo, deixando de constituir meros limites ao agir estatal para se transformar em verdadeiro norte da atuação do Legislativo, Executivo e Judiciário. E essa expansão eficacial dos direitos em questão, decorrente de sua faceta objetiva, compele os poderes constituídos a interpretar todas as normas jurídicas à luz dos valores substanciais emanados dos direitos fundamentais. É essa, portanto, a principal consequência jurídica da eficácia irradiante dos direitos fundamentais: ela impõe ao Poder Público o dever de que todas as disposições inscritas no ordenamento jurídico sejam, no momento de sua aplicação, interpretadas pelo operador do direito "com novas lentes, que terão as cores da dignidade humana, da igualdade substantiva e da justiça social, impressas no tecido constitucional". ${ }^{28}$

Essa irradiação dos direitos fundamentais por todo o sistema de normas se manifesta, segundo o seu alcance, de duas formas: (i) mediante uma projeção interna à Constituição, que orienta a compreensão dos enunciados constitucionais, delimitando no campo hermenêutico os contornos jurídicos dos direitos fundamentais e auxiliando a demarcação de sua dimensão subjetiva; (ii) por meio de uma projeção externa à Constituição, que estende a incidência do conteúdo axiológico desses direitos a todas as normas jurídicas infraconstitucionais, vinculando a interpretação de todas as disposições normativas legais e administrativas. ${ }^{29}$

Essa condição de valores essenciais que integram a medula da ordem constitucional faz com que os direitos fundamentais deixem de ser meros limites negativos à ação estatal, tornando-se também vetores e linhas diretivas que norteiam e condicionam a sua atuação positiva. ${ }^{30}$ Eles passam a orientar os comportamentos do Poder Público, indicando quais caminhos deverão ser seguidos para que as decisões axiológicas estabelecidas pelo poder constituinte sejam mais adequadamente cumpridas. Dita consequência impacta diretamente na atividade hermenêutica do Estado, pois a compreensão do significado das normas jurídicas constitucionais, convencionais, legais e administrativas será afetada pela axiologia substancial que deflui dos direitos fundamentais. A eficácia irradiante implica, assim, no dever estatal de interpretar todas as normas que compõem o sistema normativo a partir do conteúdo material dos direitos fundamentais.

No âmbito da atividade administrativa, esse efeito jurídico da dimensão objetiva dos direitos fundamentais conduz a duas implicações de grande expressão: (4.1) obriga a Administração Pública a interpretar os termos jurídicos indeterminados de modo a privilegiar os direitos fundamentais, maximizando a sua tutela;

28 SARMENTO, Daniel. A dimensão objetiva dos direitos fundamentais: fragmentos de uma teoria. In: SAMPAIO, José Adércio Leite (Org.). Jurisdição constitucional e direitos fundamentais. Belo Horizonte: Del Rey, 2003, p. 279.

29 GAVARA DE CARA, Juan Carlos. La dimensión objetiva de los derechos sociales. Barcelona: Bosch Editor, 2010, p. 21 e 72.

so RODRÍGUEZ-ARANA MUÑOZ, Jaime. Derecho Administrativo y Constitución. Granada: CEMCI, 2000, p. 104. 
(4.2) diminui as margens da discricionariedade das competências administrativas, circunscrevendo o círculo de escolhas legítimas da Administração àquelas que implementem de forma otimizada os direitos fundamentais. ${ }^{31}$

Tais repercussões devem ser levadas a sério no plano da realidade concreta, não podendo quedar encarceradas no discurso teórico. Para que isso ocorra, é necessário levar às últimas consequências a incidência direta dos direitos fundamentais sobre a atuação administrativa para que a previsão do art. $5^{\circ}$, $\S^{1} \stackrel{\circ}{ }$, não se converta em uma banalidade. Ou se reconhece que os direitos fundamentais produzem, mesmo à margem de previsões legais específicas, efeitos jurídicos concretos e relevantes, como uma tinta espessa que inunda e contamina a atividade administrativa, ou se terá de admitir, fatalmente, que sua consagração constitucional não é verdadeiramente jurídico-normativa, mas, sim, lítero-poéticorecreativa, e que, tal como uma pálida fumaça, eles podem ser facilmente soprados e afastados pela Administração Pública.

\subsection{Dever de interpretação dos termos jurídicos indeterminados à luz dos direitos fundamentais}

A primeira implicação acima apontada é a de que o Poder Público, quando se depara com expressões fluidas inseridas em enunciados normativos (tais como moralidade administrativa, boa-fé, interesse público, eficiência), deverá interpretá-los em conformidade com os valores que emanam dos direitos fundamentais. O conteúdo jurídico de tais expressões passa a ser compulsoriamente recheado com a axiologia inerente aos direitos fundamentais. E assim, o significado das fórmulas legais fluidas passa a ser necessariamente extraído de uma interpretação sistemática presidida pelos valores ínsitos aos bens jurídicos jusfundamentais.

A assertiva, na teoria, pode parecer óbvia, mas, na prática, nem sempre o é. Cite-se o exemplo do trabalhador que é contratado pelo Estado sem submeter-se a concurso, por excepcional interesse público (art. 37, IX, CF), e permanece prestando serviços à entidade estatal por mais tempo do que a lei autoriza em face de postergação ilícita do contrato de trabalho suscitada pela própria Administração. De acordo com a Súmula no 363 do Tribunal Superior do Trabalho, prevalece o entendimento de que o trabalhador faz jus somente ao salário relativo às horas trabalhadas e ao depósito dos valores referentes ao FGTS, não Ihe sendo devido o

31 As diferenças entre as noções de "conceitos jurídicos indeterminados" e "discricionariedade administrativa" são explicadas de maneira aprofundada por: PIRES, Luis Manuel Fonseca. Controle judicial da discricionariedade administrativa... Op. cit., p. 67-116. 
pagamento de qualquer outra parcela (aviso prévio, décimo terceiro salário, férias vencidas e proporcionais acrescidas do terço constitucional, FGTS com multa de $40 \%$, etc.). ${ }^{32}$ Sabe-se que os princípios da moralidade administrativa e da boa-fé incidem sobre a atividade administrativa. Isso ninguém nega nos dias atuais, ao menos no plano abstrato. O conteúdo jurídico dessas categorias, dotadas de contornos imprecisos, haverá de ser preenchido pelos valores jusfundamentais.

Indaga-se: seria adequado afirmar que se encontra em conformidade com a moralidade administrativa e com a boa-fé a conduta da Administração de prorrogar ilicitamente o contrato, fazendo o trabalhador confiar na legitimidade do seu proceder para então apropriar-se da força de trabalho do indivíduo e negar-lhe a satisfação da maior parte dos seus direitos fundamentais sociais de cunho laboral? É evidente que não. Repita-se: o significado do que vem a ser um comportamento administrativo moral e respeitoso à boa-fé deverá ser interpretado com base nos direitos fundamentais. A clara afronta a esses direitos importará, por conseguinte, uma atuação imoral e de má-fé da Administração Pública. Entender de forma contrária significa negar o discurso até aqui desenvolvido, de que os direitos fundamentais realmente vinculam diretamente o agir administrativo. Se eles não servem nem para conferir significação a termos indeterminados como esses, isso implica aceitar a sua condição de esquálida fumaça que, com um simples abano da Administração, pode ser dissipada, tornando-se algo inútil quanto à conformação das condutas estatais.

\subsection{Diminuição da discricionariedade administrativa por força dos direitos fundamentais}

A segunda consequência jurídica da eficácia irradiante dos direitos fundamentais sobre o exercício da função administrativa diz respeito à redução da esfera de discricionariedade da Administração por força da incidência dos valores protegidos por esses direitos. Nesse sentido, Justo Reyna sublinha que "os direitos fundamentais (...) operam no Estado Constitucional de Direito como condicionantes e guias do exercício da discricionariedade administrativa, impondo obrigações de fazer às autoridades administrativas". ${ }^{33}$

32 Súmula no 363 do Tribunal Superior do Trabalho: “A contratação de servidor público, após a CF/1988, sem prévia aprovação em concurso público, encontra óbice no respectivo art. 37 , II e §2º , somente lhe conferindo direito ao pagamento da contraprestação pactuada, em relação ao número de horas trabalhadas, respeitado o valor da hora do salário mínimo, e dos valores referentes aos depósitos do FGTS".

33 REYNA, Justo José. El procedimiento administrativo multidimensional como técnica regulatoria en materia ambiental, de patrimonio cultural y de pueblos originarios. A\&C - Revista de Direito Administrativo \& Constitucional, n. 50, Belo Horizonte, Fórum, p. 131-169, out./dez. 2012, p. 138. 
Asseverar que os direitos fundamentais exibem uma dimensão objetiva, que compele o Poder Público a agir em prol da sua efetivação independentemente de provocação subjetiva e a interpretar o ordenamento jurídico à luz do seu conteúdo axiológico, implica reconhecer que tais direitos tornam juridicamente ilegítimas as escolhas administrativas que, embora admissiveis sob o ângulo da legalidade estrita, não sejam as mais adequadas a realizá-los. Em outras palavras: se para exercer uma competência discricionária a Administração pode escolher entre as várias opções que Ihe são autorizadas pela lei, mas algumas delas são menos apropriadas a satisfazer de maneira otimizada o conteúdo dos direitos fundamentais, estas últimas deixam de ser admitidas pelo direito e se tornam antijurídicas, mesmo que não sejam condutas vedadas pela lei em sentido formal. Para a Administração Pública, não basta, portanto, verificar quais são as medidas que a lei lhe permite eleger. A ela compete averiguar qual é a solução mais suscetível de potencializar a tutela dos direitos fundamentais. Todas as demais serão inconstitucionais.

A diminuição das fronteiras da discricionariedade administrativa diante do caso concreto, inclusive passivel de chegar a um "grau zero", é apontada pela doutrina administrativista nacional e estrangeira. Conforme aduz Celso Antônio Bandeira de Mello, “a discrição administrativa é maior na norma de Direito do que perante a situação concreta", de sorte que o confronto entre a finalidade do enunciado normativo e as circunstâncias fáticas "pode levar, inclusive, à total disparição de discricionariedade, que, embora existente ao nível da norma, deixa de suster-se ante as peculiaridades de alguma situação em concreto". ${ }^{34}$ Na mesma senda, Luis Manuel Fonseca Pires assinala que reconhecer a existência de discricionariedade na estática da norma jurídica "não significa que diante do caso concreto necessariamente haverá uma pluralidade de decisões legítimas franqueadas à Administração Pública". ${ }^{35}$ Se a disposição normativa só confere essa margem de apreciação para que a Administração possa identificar, diante das peculiaridades fáticas, qual é a escolha que atenderá mais perfeitamente à finalidade da norma, no caso concreto deixarão de ser admitidas muitas das alternativas que abstratamente seriam aceitáveis pelo direito. Isso porque, naquela hipótese determinada, tais opções que, em tese, eram legalmente autorizadas - já não se mostram apropriadas para cumprir de maneira excelente o objetivo que inspirou a norma jurídica atributiva da competência administrativa. Bem por isso, elas escapam dos limites da discricionariedade e passam a localizar-se nos confins da antijuridicidade.

34 MELLO, Celso Antônio Bandeira de. Discricionariedade e controle jurisdicional... Op. cit., p. 36-38.

35 PIRES, Luis Manuel Fonseca. Controle judicial da discricionariedade administrativa... Op. cit., p. 199. 
Essa teoria, amplamente desenvolvida na Alemanha e há muito incorporada pela dogmática jurídica de diversos outros Estados, tal como o brasileiro, é chamada de redução da discricionariedade "a zero" (auf null). ${ }^{36}$ De acordo com Hartmut Maurer, afirmar que a Administração possui uma competência discricionária significa que ela deverá escolher entre distintos modos de condutas. Mas frente a uma situação particular, "a possibilidade de escolha pode se reduzir a uma alternativa. Isso é então o caso, quando somente ainda uma decisão é livre do vício no exercício do poder discricionário, todas as outras decisões seriam exercício do poder discricionário vicioso". ${ }^{37}$ Em tais circunstâncias, o agente se vê obrigado a adotar aquela única providência que ainda remanesce como legítima perante o direito, por ser justamente a que melhor se afina ao atingimento da finalidade da norma. Maurer aponta, então, que a influência dos direitos fundamentais e outros princípios constitucionais constitui um dos fatores que provoca essa redução "a zero" da discricionariedade. As lições do autor são expressamente acolhidas na doutrina espanhola por Eduardo García de Enterría, o qual destaca que essa limitação do âmbito de escolhas administrativas se produz especialmente "quando entram em jogo direitos fundamentais e outras regras constitucionais, ou quando se trata de obrigações legais de intervir e a Administração se abstém". ${ }^{38}$

$\mathrm{O}$ influxo dos direitos fundamentais como elemento apto a contrair a margem de opções legítimas de atuação administrativa afigura-se como uma consequência jurídica concreta da sua aplicabilidade imediata e do direito à tutela administrativa efetiva. Se eles incidem imediatamente sobre a atividade da Administração, o agente deverá sempre buscar eleger as escolhas que mais coadunem com a sua efetivação maximizada. Se compete ao Poder Público, no exercício de sua função administrativa, tutelar os direitos fundamentais de forma espontânea, integral e igualitária, é evidente que os caminhos que em tese seriam permitidos pela lei se tornarão, no caso concreto, proibidos pelo direito quando não se revelarem os mais convenientes e oportunos para emprestar uma proteção ótima aos direitos humanos.

Essa redução "a zero" do campo de discricionariedade administrativa pode se dar tanto em relação à dimensão subjetiva dos direitos fundamentais (quando um titular exige um comportamento positivo ou negativo do Estado), quanto em relação à perspectiva objetiva de tais direitos (referente ao dever do Poder Público

36 SESÍN, Domingo Juan. Administración Pública. Actividad reglada, discrecional y técnica: Nuevos mecanismos de control judicial. 2. ed. Buenos Aires: Depalma, 2004, p. 70.

37 MAURER, Hartmut. Direito Administrativo Geral. 14. ed. Trad. Luís Afonso Heck. Barueri: Manole, 2006, p. 152.

38 GARCÍA DE ENTERRÍA, Eduardo. Democracia, jueces y control de la Administración. 5. ed. Navarra: Thomson-Civitas, 2005, p. 259. 
de agir de ofício para implementar de modo universalizado as condições necessárias ao exercício e à fruição de bens jurídicos jusfundamentais). 0 direito social à moradia, em sua dupla dimensão (subjetiva e objetiva), presta-se à demonstração dessa afirmação.

A Medida Provisória ํo 2.220/01, ainda vigente, prevê o instituto da concessão de uso especial de imóvel público para fins de moradia. Ele tem por escopo regularizar a situação de pessoas que ocupam irregularmente bens públicos por não terem um local adequado para morar. Por meio dessa concessão, a Administração autoriza a permanência do cidadão no imóvel (cuja propriedade, por conta do art. 183, §3ㅇ, da CF, não pode ser adquirida por usucapião), fornecendo ao morador a segurança da posse e habilitando-o a postular a instalação e prestação de serviços públicos de forma regularizada, tais como saneamento básico e energia elétrica. Consoante o art. 1ㅇ, "aquele que, até 30 de junho de 2001, possuiu como seu, por cinco anos, ininterruptamente e sem oposição, até duzentos e cinqüenta metros quadrados de imóvel público situado em área urbana, utilizando-o para sua moradia ou de sua família, tem o direito à concessão de uso especial para fins de moradia em relação ao bem objeto da posse, desde que não seja proprietário ou concessionário, a qualquer título, de outro imóvel urbano ou rural".

Ocorre que o art. 5 da mesma Medida Provisória estabelece que "é facultado ao Poder Público assegurar o exercício do direito de que tratam os arts. 1ำ e $2^{\circ}$ em outro local na hipótese de ocupação de imóvel: I - de uso comum do povo; II - destinado a projeto de urbanização; III - de interesse da defesa nacional, da preservação ambiental e da proteção dos ecossistemas naturais; IV - reservado à construção de represas e obras congêneres; ou V - situado em via de comunicação". Onde se localiza a discricionariedade administrativa conferida ao Estado nessa disposição? Em decidir se ele irá conceder ou não o título jurídico ao morador, quando o caso se enquadrar em uma das hipóteses descritas nesses incisos, ou em deliberar entre conceder o uso naquele ou em outro local? A interpretação aqui será decisiva, pois, na primeira alternativa, a Administração teria o poder de optar entre proteger o direito fundamental à moradia ou não, ao passo que, na segunda, Ihe caberia somente verificar se é mais conveniente e oportuno satisfazê-lo naquela localidade ou em lugar diverso, tendo em vista os outros bens jurídicos afetados (v.g., proteção ao meio ambiente), não Ihe sendo permitido negar a pretensão deduzida.

Por se estar em face de uma situação que envolve um direito fundamental, que desfruta de aplicabilidade imediata e espraia o seu teor axiológico e seus efeitos jurídicos sobre todo o Poder Público, condicionando a sua interpretação em relação às normas constitucionais e infraconstitucionais, a primeira possibilidade hermenêutica é obrigatoriamente afastada, eis que acarreta menoscabo ao 
conteúdo valorativo do direito social à moradia. Aceitar que, nos casos narrados pelos incisos do art. 5ำ da MP no 2.220/01, a Administração teria a faculdade de outorgar ou não a concessão de uso especial para fins de moradia ao cidadão significaria desprezar por completo a eficácia irradiante dos direitos fundamentais, decorrente de sua dimensão objetiva, que vincula a compreensão do ordenamento jurídico realizada pelos órgãos, entidades e agentes administrativos. A opção por não assegurar o exercício do direito à concessão de uso especial nos casos do art. 5으, diversamente do que uma leitura apressada do seu caput pode fazer parecer, não se encontra dentro do espaço de discricionariedade da Administração traçado pela ordem jurídica, isto é, do círculo de escolhas legítimas que o sistema normativo autoriza que sejam licitamente selecionadas. ${ }^{39}$ Tal alternativa se situa para além dessas fronteiras: ela jaz no terreno proibido da arbitrariedade.

O exemplo acima versa sobre os impactos de um dos desdobramentos (eficácia irradiante) da dimensão objetiva dos direitos fundamentais sobre a sua dimensão subjetiva. Assim, essa força expansiva dos valores emanados de tais direitos influi no momento em que o titular do direito exige a sua satisfação perante a Administração, mediante uma provocação subjetiva. Porém, essa eficácia irradiante, que deriva da dimensão objetiva dos direitos fundamentais, também repercute sobre outro desdobramento da perspectiva objetiva, explorado no Ponto 2.2, supra: os deveres autônomos de proteção. Prossiga-se com o direito social à moradia para desenvolver a explicação.

Vale resgatar aqui o caso do número crescente de menores carentes no município de Cambará/PR, aludido no Item 3, supra. Por imposição dos arts. 6으 e 227 da Constituição Federal, o Poder Público está obrigado a tutelar objetivamente, com absoluta prioridade, o direito fundamental social a uma moradia digna das crianças e adolescentes. Esse dever é reforçado por diversos dispositivos legais inscritos no Estatuto da Criança e do Adolescente. Os meios e formas jurídicas para cumpri-lo são, de fato, muito variados e dependem de escolhas discricionárias a serem feitas pela Administração, levando em consideração as inúmeras atribuições que Ihe são endereçadas pelo ordenamento jurídico. Fala-se aqui em dimensão objetiva, mais especificamente em deveres de proteção (um dos desdobramentos dessa dimensão), pois essa incumbência deve ser executada pelo

39 No âmbito federal, foi essa a orientação que vingou, visto que a própria Administração, através da Instrução Normativa no 02/2007 da Secretaria do Patrimônio da União (órgão do Ministério do Planejamento, Orçamento e Gestão), reduziu a margem de discricionariedade administrativa nessa hipótese e eliminou expressamente a possibilidade de se recusar o direito à concessão nas situações descritas nos incisos

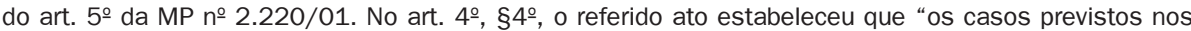
arts. $4^{\circ}$ e $5^{\circ}$ da Medida Provisória $n^{\circ} 2.220$, de 2001, não eximem o poder público da obrigação de reconhecer o direito à concessão, ainda que a moradia venha a ser exercida, em definitivo, em local diverso daquele em que é exercida a posse". 
Estado de ofício, proporcionando de maneira universalizada e igualitária o acesso à moradia aos menores abandonados, sem ser necessário, para que a conduta administrativa se torne compulsória, que algum deles venha a exigir essa prestação estatal pela via administrativa ou judicial. Por mais que haja, efetivamente, múltiplos caminhos possíveis para implementar essa obrigação, as circunstâncias fáticas podem reduzir essa margem de discrição, conduzindo a Administração a uma única opção juridicamente legítima. Já se disse que não lhe cabe decidir se vai ou não cumpri-la, nem quando irá cumpri-la. Mas mesmo em relação a como e por quais formas irá cumpri-la, o espaço de discricionariedade pode vir a ser reduzido "a zero" diante de determinada situação concreta.

O exemplo real narrado anteriormente, analisado por três órgãos diferentes do Poder Judiciário brasileiro, ${ }^{40}$ é um desses casos de transformação da competência discricionária em competência vinculada. Não havendo um abrigo sequer, de propriedade da municipalidade, destinado ao acolhimento institucional de crianças e adolescentes desamparados, e existindo cada vez mais pessoas nessa condição, o raio de alternativas legítimas da Administração para atuar nesse setor se restringe a uma só: alocar recursos humanos e materiais para a prestação adequada do serviço público de assistência social aos menores carentes. A discricionariedade foi reduzida "a zero", convertendo-se em uma conduta vinculada. ${ }^{41} \mathrm{O}$ Poder Judiciário enxergou nesse caso "poder discricionário" onde não havia: pelo contrário, tratava-se de um exemplo típico de desvio de poder por omissão. ${ }^{42} \mathrm{~A}$ propositura da ação civil pública pelo Ministério Público do Estado do Paraná, que visava combatê-la, representou uma hipótese de ressubjetivização da dimensão objetiva de um direito fundamental. O direito à moradia, por sua faceta objetiva (deveres autônomos de proteção), impunha que o Poder Público criasse as estruturas organizacionais e procedimentais para que ele pudesse ser fruído pela

40 Ver: BRASIL. Tribunal de Justiça do Estado do Paraná. Recurso de Apelação de Menores nํ 105-9. Acórdão no 7.910. Relator Des. Accácio Cambi. Conselho da Magistratura. Julgado em 09.02.1998. Disponível em: <http://www2.mp.pr.gov.br/cpca/telas/ca_igualdade_14_4_1_1.php>. Acesso em: 10 out. 2013; e BRASIL. Superior Tribunal de Justiça. Recurso Especial no 208.893/PR. Relator Min. Franciulli Netto. Segunda Turma. Julgado em: 19.12.2003. DJ 22.03.2004.

41 Dissertando sobre hipótese similar, embora tratada em termos abstratos e sem alusão a esse caso concreto ocorrido no município de Cambará, Luis Manuel Fonseca Pires manifesta-se no sentido de que a necessidade de construir uma casa de abrigo para acolher menores órfãos em um município onde não exista nenhuma consiste em um exemplo de redução da discricionariedade "a zero": "É possível, num caso com tais contornos, reconhecer que a discricionariedade administrativa deixa de existir e passa a haver uma só opção, um ato de competência vinculada a ser praticado: a construção e o aparelhamento da Casa de Abrigo" (PIRES, Luis Manuel Fonseca. Controle judicial da discricionariedade administrativa... Op. cit., p. 199).

42 SORIANO GARCÍA, José Eugenio. Hacia el control de la desviación de poder por omisión. Revista Española de Derecho Administrativo, n. 40-41, Madrid, Civitas, p. 173-193, ene./mar. 1994; MORA ESPINOZA, Álvaro Enrique. El deber de hacer de la Administración: supuestos de inactividad material y su tratamiento jurisdiccional. San José: IJSA, 2009, p. 89-97. 
coletividade. Como esse dever não foi atendido de modo satisfatório, a omissão administrativa se tornou desproporcional por esbarrar na proibição de proteção insuficiente, autorizando com isso a exigibilidade subjetiva do direito pela via da tutela coletiva.

\section{Conclusão}

Diante do exposto, cumpre apresentar as conclusões a que se chegou a respeito das consequências jurídicas da incidência das dimensões objetiva e subjetiva dos direitos fundamentais sociais na discricionariedade administrativa:

1. A aplicabilidade imediata dos direitos fundamentais sociais manifesta-se de forma diferenciada a depender da dimensão de tais direitos que se leve em consideração: (a) a subjetiva e (b) e a objetiva.

(a) Através da dimensão subjetiva, existe uma exigência por parte de algum cidadão ou de algum grupo de pessoas que, direcionando-se à Administração Pública, pretende que ela aja de alguma determinada maneira (por meio de ações ou abstenções) para respeitar, proteger ou promover alguma pretensão jurídica jusfundamental.

(b) Já na dimensão objetiva não existe nenhum pedido do titular do direito fundamental social em face da Administração. Sua natureza consiste na imposição de alguns deveres ao Poder Público, independentemente de qualquer provocação subjetiva, quanto: (i) à criação das condições necessárias para fruição desses direitos; (ii) à interpretação do ordenamento jurídico com base no conteúdo valorativo inerente a esses direitos; e (iii) à proteção dos titulares desses direitos contra si mesmos.

2. O atributo da discricionariedade administrativa apresenta consequências jurídicas diversas em relação a cada uma dessas dimensões.

(a) No caso da dimensão subjetiva, a existência ou não de discricionariedade para a concessão do direito depende da posição jurídica jusfundamental requerida, que poderá estar prevista em um enunciado normativo que confere à Administração uma competência vinculada ou discricionária. Um pedido referente ao acesso gratuito aos serviços públicos de educação básica (art. 208, I, da CF), por exemplo, deve ser atendido de modo vinculado, não havendo espaço para juízos de oportunidade e conveniência por parte do administrador público. No entanto, a questão já é diferente quando se analisa o direito fundamental à moradia (art. 6º, CF). Apesar de o art. 23, IX, da Constituição 
determinar que a União, os Estados, o Distrito Federal e o Município devem "promover programas de construção de moradias e a melhoria das condições habitacionais e de saneamento básico", o texto constitucional não delimitou exatamente o conteúdo desses programas - razão pela qual, se tal matéria for discutida por meio de um requerimento de algum cidadão, a forma como tais programas serão implementados restará albergada pelo campo da discricionariedade administrativa.

(b) Já na dimensão objetiva, as competências administrativas relativas a direitos fundamentais sociais sempre contarão com alguns elementos vinculados e outros discricionários. Por exemplo: por força do art. 6o e do art. 40, $1^{\circ}{ }^{\circ}$, III, ambos da Constituição, a Administração tem o dever de instituir um sistema de previdência para os servidores públicos. A competência, nesse ponto, é vinculada. Para além disso, porém, a Administração Pública tem discricionariedade para decidir se o serviço de previdência será prestado de forma centralizada pela Administração direta ou se será criada uma autarquia (como ocorre com o Instituto Nacional do Seguro Social - INSS) para isso.

3. Uma correta compreensão acerca dos espaços e do método de aplicação da discricionariedade administrativa nas atividades direcionadas à satisfação de direitos fundamentais sociais demonstra-se extremamente essencial. Como se demonstrou através de um caso concreto, julgado por três diferentes instâncias, no atual cenário é muito comum que a discricionariedade administrativa seja utilizada como álibi para justificar a inação da Administração Pública. No entanto, não se deve permitir que a discricionariedade administrativa seja utilizada como argumento genérico para impedir a efetiva realização de direitos fundamentais sociais, sob pena de se admitir fortes distorções à autêntica significação jurídica dessa categoria. Sendo assim, a discricionariedade administrativa deve continuar sendo utilizada pelos administradores públicos, mas com o objetivo de identificar o espaço dentro do qual eles podem, em um juízo de oportunidade e conveniência, determinar os meios mais eficazes para o atendimento dos mandamentos constitucionais e infraconstitucionais.

4. Outro importante instituto que deve ser analisado quando se está estudando a discricionariedade administrativa é a aplicabilidade imediata dos direitos fundamentais sociais, constante no art. $5^{\circ}, \S^{\circ}{ }^{\circ}$, da Constituição Federal. Afinal, é dessa característica que decorre a qualidade da eficácia irradiante das normas que preveem posições jurídicas jusfundamentais. Pelo fato de submeterem a Administração Pública ao dever de aplicá-los 
imediatamente, os direitos fundamentais fazem com que toda a atividade administrativa seja norteada para sua efetivação. Com efeito, não se mostram mais apenas como barreiras que obstaculizam a atuação do Estado, mas, principalmente, como um farol que indica o caminho pelo qual deve seguir uma Administração Pública preocupada com a realização dos dispositivos constitucionais.

5. Dessa maneira, uma das principais consequências geradas pela eficácia irradiante é fazer com que, quando o Poder Público se depare com enunciados normativos de conceitos fluidos - os chamados termos jurídicos indeterminados -, deva sempre interpretá-los tendo como base e como fim os direitos fundamentais. Ou seja, muito embora conceitos como moralidade administrativa, boa-fé, interesse público e eficiência, por exemplo, comportem em teoria variadas significações, na prática o administrador público possui a obrigação de interpretá-los em conformidade com os valores que emanam do sistema constitucional de direitos fundamentais.

6. Outra relevante decorrência da aplicação da eficácia irradiante dos direitos fundamentais sobre a função administrativa é a diminuição dos espaços de discricionariedade de que goza o administrador público para efetivar esses direitos. A lógica é a de que, por mais que para exercer determinada competência relativa a algum direito fundamental social a Administração Pública possa escolher entre diversos caminhos, se alguns deles forem menos apropriados para atender de modo otimizado o dever de satisfação desses direitos, tais opções deixam de ser autorizadas pelo direito, tornando-se condutas antijurídicas, ainda que não vedadas expressamente pela lei. Essa tese possui respaldo na doutrina nacional e estrangeira, que defende que a discricionariedade é sempre mais ampla na abstração da norma jurídica, podendo chegar a zero diante das peculiaridades dos casos concretos (sejam casos em que um titular exige um comportamento do Estado - dimensão subjetiva -, sejam casos em que existe um dever do Poder Público em agir de uma determinada maneira dimensão objetiva). 
The administrative discretion between the objective and subjective dimensions of fundamental social rights

Abstract: There is a silence of the scholars in the administrative law regarding to administrative discretion in the field of fundamental social rights. To fill this gap, the article proposes to defend three ideas: (i) there is a difference between situations involving administrative discretion when the object of analysis is the subjective dimension of fundamental rights and when the focus examined is its objective dimension; (ii) any generic references to "the discretion of the administrative competence on fundamental rights" can subvert the true meaning of this legal category, converting it into a joker of the Public Administration to cover up arbitrary omissions; (iii) the irradiant effects derived from the objective aspect of fundamental rights greatly reduces administrative discretion, being able to suppress it until the point of becoming linked the competence of the administration and force it to remove all existing barriers and create all necessary conditions to provide maximum satisfaction of these rights, and to interpret the whole legal system in the most appropriate way to stimulate the great achievement of the values underlying fundamental rights.

Keywords: Administrative discretion. Fundamental rights. Social rights. Objective dimension. Subjective dimension.

Summary: $\mathbf{1}$ Introduction - $\mathbf{2}$ The administrative discretion in relation to the subjective and objective dimensions of fundamental rights: distinctive features $\mathbf{-} \mathbf{3}$ The general reference to the "discretion of the administrative competence on fundamental rights": the risk of the Public Administration joker to cover up arbitrary omissions $\mathbf{- 4}$ Irradiating effects of fundamental rights and the reduction of administrative discretion: filling the legal empty spaces with the objective dimension - $\mathbf{5}$ Conclusion - References

\section{Referências}

ALMEIDA, Fernando Dias Menezes de. Liberdade de reunião. São Paulo: Max Limonad, 2001.

BONNARD, Roger. Les droits publics subjectifs des administrés. Revue du droit public et de la science politique en France et a l' etranger, Paris, v. 49, p. 695-728, 1932, p. 712.

BRASIL. Superior Tribunal de Justiça. Agravo Regimental no Recurso Especial no 252.083/ RJ. Relatora Min. Nancy Andrighi. Segunda Turma. Julgado em 27.06.2000. DJ 26.03.2001.

BRASIL. Superior Tribunal de Justiça. Recurso Especial oㅜ 169.876/SP. Relator Min. José Delgado. Primeira Turma. Julgado em 16.06.1998. DJ 21.09.1998.

BRASIL. Superior Tribunal de Justiça. Recurso Especial no 208.893/PR. Relator Min. Franciulli Netto. Segunda Turma. Julgado em 19.12.2003. DJ 22.03.2004.

BRASIL. Superior Tribunal de Justiça. Recurso Especial no 782.196/SP. Relatora Min. Eliana Calmon. Segunda Turma. Julgado em 13.03.2007. DJ 22.03.2007.

BRASIL. Superior Tribunal de Justiça. Recurso Ordinário em Mandado de Segurança no 19.535/RJ. Relator Min. Franciulli Netto. Segunda Turma. Julgado em 01.09.2005. DJ 31.05.2006. 
BRASIL. Supremo Tribunal Federal. Recurso Extraordinário no 423.662. Relator Min. Joaquim Barbosa. Julgado em 04.12.2009. Publicado em DJe-237, divulgado em 17.12.2009, publicado em 18.12.2009.

BRASIL. Tribunal de Justiça do Estado do Paraná. Recurso de Apelação de Menores no 105-9. Acórdão no 7.910. Relator Des. Accácio Cambi. Conselho da Magistratura. Julgado em 09.02.1998. Disponível em: <http://www2.mp.pr.gov.br/cpca/telas/ca igualdade_14_4_1_1.php>. Acesso em 10 out. 2013.

DI PIETRO, Maria Sylvia Zanella. Direito administrativo e dignidade da pessoa humana. A\&C - Revista de Direito Administrativo \& Constitucional, no 52, Belo Horizonte, Fórum, p. 13-33, abr./jun. 2013.

DI PIETRO, Maria Sylvia Zanella. Discricionariedade administrativa na Constituição de 1988. 3. ed. São Paulo: Atlas, 2012.

FERNÁNDEZ, Tomás-Ramón. De la arbitrariedad de la Administración. 5. ed. Navarra: Thomson-Civitas, 2008.

GARCÍA DE ENTERRÍA, Eduardo. Democracia, jueces y control de la Administración. 5. ed. Navarra: Thomson-Civitas, 2005.

GAVARA DE CARA, Juan Carlos. La dimensión objetiva de los derechos sociales. Barcelona: Bosch Editor, 2010.

GONZÁLEZ PÉREZ, Jesús. La dignidad de la persona y el Derecho Administrativo. A\&C Revista de Direito Administrativo \& Constitucional, n. 29, Belo Horizonte, Fórum, p. 11-35, jul./set. 2007.

HACHEM, Daniel Wunder. A dupla titularidade (individual e transindividual) dos direitos fundamentais econômicos, sociais, culturais e ambientais. Revista de Direitos Fundamentais e Democracia, v. 14, n. 14, Curitiba, p. 618-688, jul./dez. 2013.

HACHEM, Daniel Wunder. Mínimo existencial y derechos económicos y sociales: distinciones y puntos de contacto a la luz de la doctrina y jurisprudencia brasileñas. Revista Eurolatinoamericana de Derecho Administrativo, Santa Fe, v. 1, n. 1, p. 93-138, ene./jun. 2014. Disponível em: <www.dx.doi.org/10.14409/rr.v1i1.4609>.

HESSE, Konrad. Elementos de Direito Constitucional da República Federal da Alemanha. Trad. Luís Afonso Heck. Porto Alegre: Sérgio Antonio Fabris, 1998.

MASSIMINO, Leonardo F. Los derechos humanos y el derecho a la vivienda: Ios critérios judiciales. A\&C - Revista de Direito Administrativo \& Constitucional, n. 51, Belo Horizonte, Fórum, p. 29-47, jan./mar. 2013.

MAURER, Hartmut. Direito Administrativo Geral. 14. ed. Trad. Luís Afonso Heck. Barueri: Manole, 2006.

MELLO, Celso Antônio Bandeira de. Curso de Direito Administrativo. 30. ed. São Paulo: Malheiros, 2013.

MELLO, Celso Antônio Bandeira de. Discricionariedade e controle jurisdicional. 2. ed. 8. tir. São Paulo: Malheiros, 2007. 
MORA ESPINOZA, Álvaro Enrique. El deber de hacer de la Administración: supuestos de inactividad material y su tratamiento jurisdiccional. San José: IJSA, 2009.

PÉREZ LUÑo, Antonio Enrique. Los derechos fundamentales. 9. ed. Madrid: Tecnos, 2007.

PIRES, Luis Manuel Fonseca. Controle judicial da discricionariedade administrativa: dos conceitos jurídicos indeterminados às políticas públicas. 2. ed. Belo Horizonte: Fórum, 2013.

REYNA, Justo José. El procedimiento administrativo multidimensional como técnica regulatoria en materia ambiental, de patrimonio cultural y de pueblos originarios. A\&C-Revista de Direito Administrativo \& Constitucional, n. 50, Belo Horizonte, Fórum, p. 131-169, out./dez. 2012.

RODRÍGUEZ-ARANA MUÑOZ, Jaime. Derecho Administrativo y Constitución. Granada: CEMCI, 2000.

RODRÍGUEZ-ARANA MUÑOZ, Jaime. Direito fundamental à boa Administração Pública. Trad. Daniel Wunder Hachem. Belo Horizonte: Fórum, 2012.

SARLET, Ingo Wolfgang. A eficácia dos direitos fundamentais: uma teoria geral dos direitos fundamentais na perspectiva constitucional. 10. ed. Porto Alegre: Livraria do Advogado, 2010.

SARLET, Ingo Wolfgang; ZOCKUN, Carolina Zancaner. Notas sobre o mínimo existencial e sua interpretação pelo STF no âmbito do controle judicial das políticas públicas com base nos direitos sociais. Revista de Investigações Constitucionais, Curitiba, v. 3, n. 2, p. 115-141, maio/ago. 2016. Disponível em: <http://dx.doi.org/10.5380/rinc.v3i2.46594>.

SARMENTO, Daniel. A dimensão objetiva dos direitos fundamentais: fragmentos de uma teoria. In: SAMPAIO, José Adércio Leite (Org.). Jurisdição constitucional e direitos fundamentais. Belo Horizonte: Del Rey, 2003.

SESÍN, Domingo Juan. Administración Pública. Actividad reglada, discrecional y técnica: Nuevos mecanismos de control judicial. 2. ed. Buenos Aires: Depalma, 2004.

SORIANO GARCíA, José Eugenio. Hacia el control de la desviación de poder por omisión. Revista Española de Derecho Administrativo, n. 40-41, Madrid, Civitas, p. 173-193, ene./ mar. 1994.

VALLE, Vanice Regina Lírio do. Judicial adjudication in housing rights in Brazil and Colombia: a comparative perspective. Revista de Investigações Constitucionais, Curitiba, vol. 1, n. 2, p. 67-102, maio/ago. 2014. Disponível em: <http://dx.doi.org/10.5380/rinc.v1i2.40511>.

Informação bibliográfica deste texto, conforme a NBR 6023:2002 da Associação Brasileira de Normas Técnicas (ABNT):

HACHEM, Daniel Wunder. A discricionariedade administrativa entre as dimensões objetiva e subjetiva dos direitos fundamentais sociais. Direitos Fundamentais \& Justiça, Belo Horizonte, ano 10, n. 35, p. 313-343, jul./dez. 2016. 